\title{
Diplomasi Vaksin Covid-19 dan Budaya Anarki dalam Sistem Internasional

\author{
Covid-19 Vaccine Diplomacy and Cultures of Anarchy in The International System
}

\author{
Ramdhan Muhamin ${ }^{1}$, Rizal A Hidayat ${ }^{2}$, Eldha Mulyani ${ }^{3}$ \\ ${ }^{1}$ Dosen Prodi Ilmu Hubungan Internasional, Universitas Al-azhar Indonesia, \\ ${ }^{2}$ Dosen Prodi Ilmu Hubungan Internasional, Universitas Al-azhar Indonesia, \\ ${ }^{3}$ Peneliti Laboratorium HI, Prodi Ilmu Hubungan Internasional, Universitas Al-azhar Indonesia \\ email: ${ }^{1}$ ramdhan.muhaimin@uai.ac.id, ${ }^{2}$ rizal.aditya@uai.ac.id, ${ }^{3}$ eldhmlyn@gmail.com
}

\section{Riwayat Artikel \\ Diterima: 1 Agustus 2021 \\ Direvisi: 20 Oktober 2021 \\ Disetujui: 29 Oktober 2021}

doi: $10.22212 /$ jp.v12i1.2345

\begin{abstract}
To fight the Covid-19 pandemic, several countries, through their pharmaceutical companies, conduct research and production of vaccines. Efforts to invent a vaccine are racing with the rapid mutation of Covid-19. The World Health Organization with GAVI (Global Alliance for Vaccines and Immunization) and CEPI (Coalition for Epidemic Preparedness Innovations) initiated a collaborative forum called Covid-19 Vaccine Global Access (COVAX). The goal there is justice and equity in the distribution of vaccines throughout the world. Although strategic efforts to deal with the Covid-19 pandemic are carried out multilaterally through COVAX, many countries have also taken bilateral steps to get their vaccine needs. On the other hand, the Covid-19 vaccine diplomacy that took place in an anarchic international system showed three different cultural patterns, namely Hobbesian (conflictual), Lockean (competitive), and Kantian (cooperative). By using a qualitative approach, this study analyzes three cultural patterns of anarchy in vaccine diplomacy. Data collection techniques in this research are based on library research. The theory used in this research is diplomacy and cultures of Anarchy in Constructivism approach. From this research, it was found that the COVAX is a representation of the cooperative pattern carried out by countries in overcoming the Covid-19 pandemic. But apart from that, there is also Hobbesian or conflictual diplomacy between the United States and China. Meanwhile, competitive diplomacy can be seen in the competition among vaccine-producing countries.
\end{abstract}

Keywords: Vaccine Diplomacy; Anarchy; Covid-19; International System; Virus 
Anarki dalam Konstruktivisme yang dikembangkan Alexander Wendt. Dari penelitian ini, ditemukan wadah COVAX merupakan representasi pola kooperatif yang dilakukan negara-negara dalam mengatasi pandemik Covid-19. Namun selain itu, terjadi juga diplomasi ala Hobbesian atau konfliktual seperti yang terjadi antara Amerika Serikat dan China. Sedangkan diplomasi yang bersifat kompetitif terlihat pada persaingan di antara negara-negara produsen vaksin.

Kata Kunci: Diplomasi Vaksin; Budaya Anarki; Covid-19; Sistem Internasional; Virus

\section{Pendahuluan}

Wabah Coronavirus Desease 2019 (Covid-19) muncul pertama kali pada akhir tahun 2019 di Wuhan, China. Covid-19 kemudian menyebar dengan cepat ke berbagai negara bersamaan dengan pergantian tahun ke 2020. Virus ini masih memiliki identik dengan virus flu Severe Acute Respiratory Syndrome (SARS) yang pernah muncul pada 2002 dan Middle East Respiratory Syndrome (MERS) pada 2012. Jumlah korban yang terinfeksi virus ini terus bertambah hingga menembus 249,6 juta jiwa dengan kematian mencapai lebih dari 5 juta jiwa, per 6 November 2021. ${ }^{1}$ Di Indonesia, hingga di hari yang sama jumlah kasus Covid-19 telah mencapai 4,2 juta jiwa, dengan angka kematian mencapai 143 ribu jiwa lebih. ${ }^{2}$

Covid-19 menjadi tantangan besar bagi negara-negara di dunia. Infrastruktur kesehatan setiap negara hampir tidak siap untuk menghadapi dahsyatnya serangan pandemi Covid-19. Untuk pertama kalinya, demi menghadapi wabah, semua negara memprioritaskan penyediaan fasilitas kesehatan, terutama untuk mendeteksi orang dengan gejala Covid-19. ${ }^{3}$

Pandemi Covid-19 mengundang beragam spekulasi dan analisis dari yang bersifat ilmiah,

1 Covid-19 Corona Virus Pandemic", Worldometer, diakses pada 11 September 2021, https://www. worldometers.info/coronavirus/.

2 Satuan Tugas Penanganan Covid-19, "Data Sebaran Covid-19 di Indonesia", Satgas Covid19, Diakses pada 11 September 2021, https://covid19.go.id/.

3 Smruti S. Pattanaik, "Covid-19 Pandemik and India's Regional Diplomacy". Sage Journals. 28-1, (Maret 2021), 92. kritis, hingga konspiratif. Tidak hanya dimensi kesehatan, pandemi ini secara simultan berpengaruh aspek ekonomi, perdagangan, sosial, informasi, teknologi, lingkungan hingga politik. Tidak hanya bilateral, regional, tapi juga dimensi multilateral-global.

Sebagaimana virus SARS dan MERS, pandemi Covid-19, bukanlah yang pertama sebagai patogen di era modernisme. Era panjang modernisme diwarnai wabah penyakit yang tidak sedikit menimbulkan kematian, baik skala regional maupun global. Mengutip dari World Health Organization (WHO), sejak Revolusi Industri 1850, dunia mengalami sepuluh kali pandemi virus. ${ }^{4}$ Sedikitnya 335 jenis virus baru ditemukan dapat menginfeksi manusia sejak tahun 1940 hingga 2004. Dari jumlah tersebut, 72 persen virus berasal dari satwa liar. ${ }^{5}$ Pada 1889-1890, virus flu menyebar cepat di Eropa dalam lima pekan menewaskan hingga satu juta orang. Penyebaran cepat terjadi setelah penemuan mesin uap dan alat transportasi darat. Flu ini dimulai dari St.Petersburg Rusia. Meskipun saat itu belum ada pesawat terbang. ${ }^{6}$

Tahun 1916, Amerika Serikat diserang wabah Polio yang menginfeksi 27.000 orang di New York. Sekitar 6.000 jiwa meninggal akibat wabah tersebut. Virus ini baru dapat dihentikan tahun 1954 setelah ditemukan vaksin. Bersamaan dengan wabah ini, di

\footnotetext{
$4 \quad$ Fakultas Kehutanan IPB, "10 Wabah Global Terburuk di Era Modern”, Forest Digest, 23 Mei 2020, diakses pada 27 Juli 2021, https://www.forestdigest.com/ detail/525/10-wabah-global-terburuk-di-era-modern.

5 Fakultas Kehutanan IPB, "10 Wabah Global”

6 Fakultas Kehutanan IPB, "10 Wabah Global”
} 
dataran Eropa terjadi lagi wabah flu. Tahun 1918-1920 wabah Flu Spanyol menginfeksi jutaan orang di Eropa dan dunia. Korban meninggal akibat wabah ini diperkirakan mencapai 50 juta orang. Dunia menyebut wabah ini sebagai "Flu Spanyol" karena laporan pertama yang diberitakan Reuters London adalah serangan demam terhadap 100.000 orang hanya dalam dua pekan pada 1918 di Madrid. ${ }^{7}$ Virus ini diyakini sebagai efek dari pengembangan teknologi yang digunakan dalam rangka Perang Dunia di Eropa. Penyebarannya melalui mobilisasi tentara dan kolonialisme di Asia dan Afrika.

Setelah vaksin polio ditemukan 1954, pada 1957 merebak wabah flu burung. Kasus pertama virus flu ini terjadi di Singapura pada Februari 1957 yang menyebar ke Hong Kong pada April 1957, dan menyebar ke kota-kota pesisir Amerika. Selama setahun pandemi diperkirakan 1,1 juta orang meninggal akibat virus flu tersebut. Selanjutnya pada 1981, muncul virus HIV penyebab penyakit AIDS. Virus ini berasal dari simpanse di Afrika Barat lalu menulari manusia. Diperkirakan lebih dari 35 juta orang meninggal akibat virus ini sejak kemunculannya hingga akhir abad ke-20.

Tahun 2002-2004, virus Flu SARS menyerang 17 negara. Virus ini pertama kali muncul di China yang berasal dari kelelawar, menginfeksi trenggiling lalu bermutasi dan menular ke manusia. Penularannya lambat, namun persentase kematiannya cukup tinggi. Dari 8,098 kasus selama dua tahun, terdapat 774 kematian. ${ }^{8}$ Kemudian tahun 2009-2010, kelompok virus baru H1N1 yang berasal dari babi ditemukan di Meksiko, lalu menyebar ke seluruh dunia dengan korban meninggal sejumlah 575.000 jiwa. Sementara virus MERS (Middle East Respiratory Syndrome) tahun 2012-2018 yang berasal dari Timur Tengah, telah menginfeksi 2.500 orang dengan 862 kematian.

$7 \quad$ Fakultas Kehutanan IPB, “10 Wabah Global”.

8 Fakultas Kehutanan IPB, "10 Wabah Global".
Di Kongo, Afrika, muncul kasus virus ebola pertama kali tahun 1976. Namun penularan virus ini menjadi pandemi pada tahun 2014. Virus ebola telah menginfeksi 28.600 orang dengan jumlah kematian mencapai 11.325. Virus yang berasal dari kelelawar ini belum ditemukan vaksinnya hingga hari ini. Jauh sebelum Revolusi Industri abad ke-19, pandemi black death meledak di Eropa abad ke-14 M.

Pandemi Covid-19 menyebar di 200 negara di dunia. Hal ini kemudian mendorong terjadinya diplomasi vaksin di antara aktor-aktor negara. Pandemi Covid-19 secara jelas mempromosikan kesadaran kolektif multilateral bahwa pandemik ini harus diselesaikan secara bersama-sama, saling bekerjasama dan gotong royong. Dari perspektif rasional, Pandemi Covid-19 juga memperlihatkan kepentingan nasional setiap negara demi mempertahankan kedaulatan sosial, keamanan dan ekonomi. World Health Organization (WHO) membentuk wadah aliansi yaitu Covid-19 Vaccine Global Access (COVAX) yang beranggotakan 183 negara dalam upaya merespon perlawanan terhadap wabah.

Diplomasi vaksin merupakan bentuk diplomasibaru(new diplomacy)yangberdasarkan pada semangat multilateral dan keterbukaan serta transparansi dalam diplomasi. Sehingga distribusi vaksin di dunia tersalurkan secara adil dan merata untuk perlindungan populasi secara global. ${ }^{9}$ Kehancuran sosial yang disebabkan oleh pandemi penyakit di masa lalu, salah satunya karena tidak adanya sistem diplomatik yang terbuka di antara aktor-aktor dalam lingkungan internasional. Tidak ada kerjasama internasional dalam menghadapi wabah penyakit yang melanda dunia.

Artikel ini berupaya secara kritis menganalisis praktik diplomasi terkait

9 Global Vaccine Alliance, "The Power of Partnership", GAVI, diakses 27 Juli 2021, https://www.gavi.org/ouralliance/about. 
mengatasi pandemi Covid-19 di tingkat global. Sistem lingkungan internasional yang anarki turut mendorong diplomasi vaksin yang dinamis di antara negara-negara.

\section{Kerangka Teori}

\section{Diplomasi Vaksin}

Sejak 1922SirErnestSatow mendefinisikan diplomasi sebagai aplikasi intelijen dan taktik untuk menjalankan hubungan resmi antara pemerintah berdaulat dengan negara-negara jajahannya. ${ }^{10}$ Negara melalui perwakilan resmi dan aktor-aktor lain berusaha menyampaikan kepentingan nasional khusus atau yang lebih luas, yang dilakukan melalui korespondensi, pembicaraan tidak resmi, saling menyampaikan cara pandang, lobby, kunjungan, dan aktivitasaktivitas lainnya yang terkait. ${ }^{11}$ Meskipun diplomasi berhubungan dengan aktivitasaktivitas yang damai, dapat juga terjadi di dalam kondisi perang atau konflik, karena tugas utama diplomasi tidak hanya manajemen konflik, tetapi juga manajemen perubahan dan pemeliharaannya dengan cara melakukan persuasi yang terus menerus di tengah-tengah perubahan yang berlangsung. ${ }^{12}$

Dalam dunia kesehatan global, diplomasi vaksin bukan hal baru. Sejak vaksin pertama kali ditemukan dalam sejarah modern tahun 1789, diplomasi sebagai metode untuk penggunaan vaksin di Russia, Turki, Spanyol hingga suku asli Amerika di wilayah Meksiko dan Amerika Serikat mulai diperkenalkan Edward Jenner pada tahun $1800 .{ }^{13}$ Ada dua bentuk diplomasi terkaitvaksin, yaitu diplomasi vaksin (Vaccine Diplomacy) dan diplomasi sains

10 Sir Ernest Satow, A Guide to Diplomatic Practice, (New York: Longman Green \& Co, 1922), hal. 1.

11 RP Barston, Modern Diplomacy, (New York: Longman, 1997), hal. 1.

12 Adam Watson, The Dialogue Between States, (London: Methuem, 1984), hal. 223.

13 J Diane Pearson, "Medical diplomacy and the American Indian: Thomas Jefferson, the Lewis and Clark Expedition, and the subsequent effects on American Indian health and public policy". Wicazo S Review 19 (2004): hal. 105-130. vaksin (Vaccine Science Diplomacy). Diplomasi vaksin (Vaccine Diplomacy) merupakan percabangan dari diplomasi kesehatan global (Global Health Diplomacy) yang bergantung kepada penggunaan dan pengiriman vaksin. Sedangkan diplomasi sains vaksin (Vaccine Science Diplomacy) adalah percampuran unik dari kesehatan global dan diplomasi sains. ${ }^{14}$ Diplomasi vaksin merujuk kepada hampir semua aspek dari diplomasi kesehatan global yang terbatas pada penggunaan dan pengiriman vaksin serta meliputi beberapa organisasi strategis seperti GAVI (Global Alliance for Vaccines and Immunization), WHO (World Health Organization), Gates Foundation, dan organisasi internasional penting lainnya. ${ }^{15}$ Inti diplomasi vaksin adalah potensinya sebagai intervensi kemanusiaan dan pembuktian perannya dalam memediasi perselisihan dan bahkan genjatan senjata selama kampanye vaksinasi. ${ }^{16}$

Kickbusch dan Lokeny mendefinisikan diplomasi kesehatan global sebagai 'sistem organisasi dan komunikasi serta proses negosiasi yang membentuk lingkungan kebijakan global di bidang kesehatan dan determinannya. ${ }^{17}$ Dalam diplomasi kesehatan global, elemen kunci tidak lagi terletak pada diplomat, melainkan berbagai ahli dari berbagai bidang ilmu dan disiplin yang terlibat untuk memecahkan masalah kesehatan. ${ }^{18}$

Katz R., Kornbles, Arnold G, dan Lief Fischer dalam jurnal mereka berjudul "Defining Health Diplomacy: Changing Demands in the Era of Globalization" melakukan kategorisasi pada aspek diplomasi

14 Peter J Hotez, "Vaccine Diplomacy: Historical Perspectives and Future Directions", PLoS Negl Trop, Dis 8(6), (Juni 2014), hal. 1-7

15 Peter J Hotez, dkk., "Vaccine Diplomacy", 2.

16 Peter J Hotez, dkk., "Vaccine Diplomacy", 2.

17 Kickbusch I, Lokeny M, "Global health diplomacy: five years on”, Bull World Health Organ 91 (Maret 2013), hal. 159-159A.

18 Kickbusch I, Silberschmidt G, Buss P, "Global Health Diplomacy: The Need for New Perspectives, Strategic Approaches and Skills in Global Health", Bull World Health Organ 85 (Maret 2007), 230-232. 
kesehatan global kepada tiga hal. Pertama, diplomasi inti (core diplomacy). Ini merujuk kepada bentuk 'negosiasi Westphalia Klasik' di antara negara-negara baik bilateral maupun multilateral. ${ }^{19}$

Kedua, diplomasi para pemangku kepentingan (stakeholder diplomacy), yaitu negosiasi yang merujuk pada aktor di antara negara atau antara negara dengan lembaga internasional seperti WHO, GAVI Alliance, United States Agency for International Development (USAID), dan NGO. Ketiga, diplomasi informal, yang dilakukan melalui kemitraan ilmiah peer-to-peer, seperti penyandang dana swasta seperti Bill \& Melinda Gates Foundation. ${ }^{20}$

Diplomasi vaksin secara karakteristik menggambarkan diplomasi baru yang terbuka (new diplomacy) karena diplomasi ini menuntut sifat kerjasama (corporation), akomodasi (accommodation), dan oposisi (opposition). Berbeda dengan diplomasi lama (old diplomacy) yang memiliki sifat negosiatif, konsensif, konfliktual (making conflict), dan penuh ancaman (threat). Diplomasi baru biasanya mengusung tema-tema utama seperti Hak Asasi Manusia (HAM), intervensi kemanusiaan, hak-hak pekerja, isu lingkungan nasional maupun lintas batas, isu lingkungan global (perubahan iklim, pencurian ikan, hingga luar angkasa), bioteknologi, regionalisme perdagangan bebas, hingga kesehatan. Pada bentuk diplomasi baru, obyek tanggung jawab dari proses diplomasi tidak lagi negara an sich, tetapi diarahkan kepada kemanusiaan. Bahwa diplomasi pada dasarnya dilakukan tidak semata untuk kepentingan nasional negara, tetapi kepentingan pertanggungjawaban adalah melindungi warga negara (a responsibility of government to protect citizens from harm).

19 Katz R, Kornblet S, Arnold G, Lief E, Fischer JE, "Defining Health Diplomacy: Changing Demands in the Era of Globalization", Milbank Quarterly 89, (September 2011), hal. 503-523.

20 Katz R dkk., "Defining Health Diplomacy".
Diplomasi multijalur (multitrack diplomacy) yang dikembangkan dalam diplomasi baru memiliki kesesuaian dengan misi diplomasi vaksin yang memang bertujuan kepada keamanan kemanusiaan (human security) dan kepentingan nasional (national interest). Diplomasi multijalur adalah pengembangan dari diplomasi jalur kedua (Track Two Diplomacy). ${ }^{21}$

John W McDonald dan Dr. Louise Diamond menerbitkan buku "Multi-Track Diplomacy" (1991) sebagai sebuah pendekatan perdamaian yang terdiri dari sembilan jalur diplomasi, yaitu pemerintah (jalur satu); nonpemerintah/professional (jalur dua); bisnis perdagangan (jalur tiga); individual warga negara (jalur empat); penelitian, pelatihan dan pendidikan (jalur lima); aktivisme lingkungan dan perdamaian (jalur enam); gerakan keagamaan (jalur tujuh); yayasan atau organisasi pendanaan (jalur delapan); dan komunikasi media massa (jalur sembilan). ${ }^{22}$ Dalam konteks ini, diplomasi vaksin dilihat sebagai diplomasi baru modern yang memiliki sifat keterbukaan dan kerjasama. Secara praktis, negara-negara melakukan diplomasi vaksin yang menempuh berbagai jalur (multitrack diplomacy) dalam rangka mencapai kepentingan nasional dan kerjasama.

\section{Budaya Anarki}

Para ilmuwan bersepakat bahwa kondisi sistem internasional pasca Perang Dunia berada pada situasi yang anarki. Alexander Wendt menyimpulkan situasi ini mendorong kepada tiga pola budaya diplomatis yang terkonstruksi oleh tipe interaksi antar negara, yaitu Hobbesian, Lockean, dan Kantian. Interaksi dengan negara lain menciptakan satu struktur identitas dan kepentingan daripada

\footnotetext{
21 Sukawarsini Djelantik, Diplomasi antara Teori dan Praktik, (Yogyakarta: Graha Ilmu, 2008), hal. 21.

22 John W. McDonald, "The Institute for Multi-Track Diplomacy”, Journal of Conflictology, Vol. 3, Iss. 2 (2012), hal. 66-70.
} 
yang lain; struktur tidak mempunyai eksistensi atau kekuatan kausal selain dari proses. ${ }^{23}$

Pertama, pola Hobbesian (Thomas Hobbes) yaitu keadaan anarki dalam struktur sosial menciptakan suatu keadaan dimana aktor negara lain yang sifatnya setara dianggap sebagai musuh sehingga agar dapat bertahan dalam struktur tersebut negara harus saling menghancurkan satu sama lain agar dapat bertahan (survive). Negara saling memandang sebagai musuh sehingga membentuk pola yang konfliktual. ${ }^{24}$

Kedua, pola budaya anarki Lockean (John Locke), dimana dalam struktur tersebut negara-negara yang sifatnya setara saling bersaing antara satu sama lain sehingga dapat bertahan (survive), disini negara saling melumpuhkan namun tidak sampai menghancurkan. Sehingga terbentuk pola interaksi yang kompetitif. ${ }^{25}$ Ketiga, pola budaya anarki Kantian (Immanuel Kant). Pola ini adalah kebudayaan anarki yang sifatnya saling berteman dan bekerjasama. Budaya Kantian di kalangan demokrasi liberal yang terkonsolidasi sejak Perang Dunia Ke-2. ${ }^{26}$ Bagi Kenneth Waltz (1979), sistem internasional terdiri dari beberapa kekuatan besar yang masing-masing berusaha untuk bertahan karena sistem berjalan secara anarkis (suatu kondisi yang dihasilkan karena tidak adanya otoritas sentral yang dapat mengaturnya). Di dalam kondisi yang anarkis seperti itu, setiap negara akan mempertahankan dirinya sendiri. ${ }^{27}$

Ketika situasi anarki ini berkembang, diplomasi yang terjadi dalam system

23 Alexander Wendt, Social Theory of International Politics, (Cambridge: Cambridge University Press,1999), hal. 257.

24 Robert Jackson dan Georg Sorensen, Pengantar Studi Hubungan Internasional: Teori dan Pendekatan, (Yogyakarta: Pustaka Pelajar, 2016),378.

25 Robert Jackson et al, Pengantar Studi Hubungan Internasional, 380.

26 Robert Jackson et al, Pengantar Studi Hubungan Internasional, 380.

27 Robert Jackson et al, Pengantar Studi Hubungan Internasional, 113. internasional bertransformasi kepada pola yang disebut sebagai new diplomacy (diplomasi baru) atau open diplomacy (diplomasi terbuka). Pola diplomasi ini lebih menekankan kepada multilateralisme secara terbuka dan tidak rahasia. Pola ini berawal dari Versailles Treaty (Perjanjian Versailles) yang diinisiasi AS setelah Perang Dunia I. Kehadiran Liga Bangsa-Bangsa (Nations League), setelah itu Persatuan BangsaBangsa (United Nations), ini yang dibaca Wendt sebagai pola diplomasi Kantian dan diyakini dapat mencegah perang. Wendt mengembangkan pemikiran dari Immanuel Kant tentang teori Perdamaian Demokratik.

Ketiga pola diplomasi ini terimplementasi di lingkungan internasional dalam konteks perlawanan terhadap Covid-19. Langkahlangkah diplomatis untuk mendapatkan vaksin dapat bersifat kompetitif dan kooperatif. Namun di luar itu, konflik antara negara-negara produsen vaksin terbesar dunia juga tidak terhindarkan, terutama dalam diplomasi jalur terakhir yang memanfaatkan kekuatan komunikasi media massa, seperti dalam konflik antara China dan AS.

\section{Metode Penelitian}

Penelitian ini menggunakan metode kualitatif yakni berupaya mencari makna, pemahaman, pengertian tentang suatu fenomena, kejadian, maupun kehidupan manusia dengan terlibat langsung, dan atau tidak langsung dalam setting yang diteliti, kontekstual, dan menyeluruh. ${ }^{28}$ Namun dalam penelitian ini, peneliti tidak terlibat langsung ke dalam objek penelitian.

Sementara Cresswell berpandangan bahwa penelitian kualitatif lebih menekankan pada peneliti sebagai key instrument. Peneliti adalah orang yang mengumpulkan, memeriksa, dan menafsirkan informasi serta data yang

\footnotetext{
28 A. Muri Yusuf, Metode Penelitian Kuantitatif, Kualitatif, dan Penelitian Gabungan. (Jakarta: Kencana, 2019), hal. 328.
} 
didapatkannya baik dari wawancara atau dokumen kepustakaan secara mandiri. ${ }^{29}$

Fokus penelitian ini pada praktik diplomasi vaksin yang dilakukan negaranegara di dunia dalam menghadapi pandemik Covid-19. Praktik diplomasi vaksin merupakan bentuk diplomasi baru (new diplomacy) karena menjadikan perlindungan kemanusiaan sebagai objek utama diplomasi. Meski demikian, dalam sistem internasional yang anarki, diplomasi vaksin tidak selalu terwujud dalam satu model hubungan, melainkan ada kerjasama, kompetisi, bahkan konfliktual. Model-model ini muncul sebagai konsekuensi multiefek dari pandemik Covid-19 di berbagai sektor kehidupan.

Untuk menganalisa fokus tersebut, penelitian ini menghimpun data dari sumbersumber kepustakaan (library research) dan berbagai informasi dari tautan-tautan resmi ataupun media massa. Kemudian dianalisis menggunakan pendekatan teori diplomasi dan budaya anarki dalam pendekatan konstruktivisme. Yaitu menganalisa informasiinformasi yang diperoleh tentang interaksi antar-negara dalam menghadapi pandemi Covid-19.

\section{Pandemi Covid-19}

Setahun setelah Covid-19 dinyatakan sebagai Public Health Emergency of International Concern (PHEIC) atau secara sederhana adalah 'pandemi', beberapa kandidat vaksin terus dikembangkan. Secara global, para ilmuwan dan perusahaan-perusahaan vaksin telah berupaya menciptakan vaksin Covid-19 yang mustahil dapat diselesaikan dalam waktu kurang dari setahun karena harus melalui tahapan-tahapan klinis yang disyaratkan secara ilmiah oleh WHO. Upaya itu juga dilakukan melalui kolaborasi global, teknologi inovatif, dan berbagi pengetahuan melalui wadah kolaboratif COVAX Initiative.

29 A. Muri Yusuf, Metode Penelitian Kuantitatif, 329.
Saat ini lebih dari 60 vaksin Covid-19 sedang dalam pengembangan klinis yang berpacu dengan perkembangan Covid-19 yang terus bermutasi dengan cepat. Namun setidaknya 10 vaksin telah disetujui oleh National Regulatory Authorities (NRA) serta otoritas regional seperti European Medicines Agency. ${ }^{30}$

Menghadapi situasi buruk seperti ini, sejumlah negara di dunia berkolaborasi dan berkompetisi untuk menemukan vaksin yang dapat memutus mata rantai wabah Covid-19. Di sisi lain, banyak pemimpin negara yang juga meyakini strategi kekebalan komunitas (herd immunity) sebagai cara lain melemahkan Covid-19. Ditemukannya vaksin di berbagai negara seperti di AS, Inggris, dan China telah memberikan semangat baru terhadap pulihnya roda perekonomian dunia. ${ }^{31}$ Namun hal tersebut masih memunculkan masalah baru yakni seberapa ampuh vaksin-vaksin yang telah ditemukan ini dalam mencegah penyebaran virus yang semakin cepat, serta ketidaksetaraan akses terhadap vaksin bagi semua negara di seluruh dunia.

Hingga Maret 2021, China masih mendominasi sebagai negara dengan produksi vaksin terbanyak, mencapai 141 juta dosis. Vaksin Covid-19 China dengan brand Sinovac telah dikirim ke lebih dari 80 negara untuk kebutuhan pasar ataupun penggunaan darurat (emergency use listing/EUL). Di antaranya, 53 negara penerima vaksin secara gratis dan 27 negara berpenghasilan menengah membayar untuk dosis vaksin buatan China tersebut. Dengan mengirimkan vaksin ke negara-negara berkembang, Beijing telah membingkai dirinya sebagai "solusi" untuk pandemi daripada

30 Global Vaccine Alliance, "Covid-19 Vaccines are Now Approved Some Countries: What will it take Approve them?", GAVI, diakses 28 Juli 2021. https://www. gavi.org/vaccineswork/Covid-19-vaccines-are-nowapproved-some-countries-what-will-it-take-approve.

31 Humphrey Wangke, "Diplomasi Vaksin Indonesia untuk Kesehatan Dunia”. Info Singkat DPR. Vol.XIII, No 1, (Januari 2021) 8. 
sebagai "asal mula" pandemi Covid-19. ${ }^{32}$

Pada posisi kedua, AS telah memproduksi 103 juta dosis vaksin. Vaksin Moderna didanai oleh Lembaga Nasional untuk Penyakit Alergi dan Infeksi (The National Institute of Allergy and Infectious Diseases/NIAID) yang merupakan institusi di bawah Kementerian Kesehatan Amerika Serikat. ${ }^{33}$ Sementara perusahaan farmasi yang pernah menciptakan vaksin bagi virus Ebola, Johnson \& Johnson yang juga dari Amerika Serikat, berkomitmen untuk mendisitrubusikan sebanyak 500 juta dosis vaksis ke seluruh dunia melalui COVAX Initiative. $^{34}$

Vaksin Pfizer buatan perusahaan farmasi asal Jerman, telah memproduksi 70 juta dosis vaksin. Inggris sebagai negara pertama yang menyetujui penggunaan vaksin ini karena kolaborasi BioNTech dengan Pfizer. Pfizer mengklaim efikasi vaksinnya mencapai 95\% terhadap Covid-19. Sedangkan India telah memproduksi vaksin sebanyak 43 juta dosis sebelum negeri tersebut dilanda varian delta. Angka ini di atas Inggris yang baru memproduksi vaksin AstraZeneca sebanyak 12,2 juta dosis vaksin.

\section{Diplomasi Vaksin dalam 'Kerjasama' dan 'Kompetisi'}

Organisasi Kesehatan Dunia (World Health Organization) bergerak cepat setelah Covid-19 dinyatakan sebagai pandemik global pada akhir 2019, dengan membentuk wadah kolaboratif yang disebut COVAX, bersama GAVI (Global Alliance for Vaccines and Immunization) dan CEPI (Coalition for Epidemic Preparedness Innovations). ${ }^{35}$ Wadah kolaboratif ini bertujuan untuk mempercepat

32 Suisheng Zhao, "Why China's vaccine diplomacy is winning". East Asian Forum, 29 April 2021, diakses pada 20 Juni 2021, https://www.eastasiaforum. org/2021/04/29/why-chinas-vaccine-diplomacy-iswinning.

33 Global Vaccine Alliance, "Covid-19 Vaccines".

34 Global Vaccine Alliance, "Covid-19 Vaccines".

35 Global Vaccine Alliance, "Covid-19 Vaccines". pengembangan dan pembuatan vaksin Covid-19, serta menjamin akses yang adil dan merata bagi setiap negara di dunia. ${ }^{36}$ Indonesia sendiri menyatakan ketertarikan untuk bergabung dengan kolaborasi COVAX sejak Oktober 2020. Menteri Luar Negeri RI Retno Marsudi menyatakan Indonesia berhak menerima bantuan resmi Official Development Assistance (ODA) di dalam COVAX Advanced Market Commitment (COVAX AMC) untuk penyediaan vaksin Covid-19 dalam kerangka multilateral. $^{37}$ Melalui jalur kolaborasi tersebut, Indonesia hingga saat ini telah mengamankan 440 juta dosis vaksin Covid-19 hingga akhir 2021. Jumlah vaksin yang telah diterima mencapai 173 juta dosis. ${ }^{38}$

Lebih dari 180 negara telah bergabung ke dalam COVAX. Hal ini menunjukkan semangat diplomasi vaksin secara multilateral dalam menghadapi pademik Covid-19 melalui pendistribusian vaksin yang adil dan merata di seluruh dunia. ${ }^{39}$ Meski demikian, jalur-jalur bilateral juga seringkali ditempuh karena sifat penularan Covid-19 yang sangat dinamis. Faktor kesenjangan jumlah populasi dan tingkat efikasi vaksin yang berbeda-beda seringkali akhirnya membuat negara-negara berebut dalam mendapatkan vaksin.

Perusahaan-perusahaan farmasi China dinilai lebih siap daripada negara Barat untuk memberikan kesepakatan lisensi memproduksi vaksin di luar negeri. Sebagai

36 Global Vaccine Alliance, "Covid-19 Vaccines".

37 Nur Aivanni, "Indonesia Bergabung dalam COVAX", Media Indonesia, 16 Oktober 2021, diakses pada 28 Juli 2021, https://mediaindonesia.com/ internasional/353486/menlu-indonesia-bergabungdalam-covax-amc.

38 Ratih Waseso, "Indonesia Telah Mengamankan 440 Juta Dosis Vaksin Covid-19”, KONTAN, 29 Juli 2021, diakses pada 29 Juli 2021, https://nasional.kontan. co.id/news/pemerintah-telah-mengamankan-440-jutadosis-vaksin-Covid-19.

39 Khomarul Hidayat, "WHO: Sudah 184 Negara Bergabung dengan COVAX untuk Dapat Akses Setara Vaksin Corona", KONTAN, 20 Oktober 2020, diakses pada 27 Juli 2021, https://internasional.kontan.co.id/ news/who-184-negara-sudah-bergabung-dengan-covaxuntuk-dapat-akses-setara-vaksin-corona. 
contoh, Indonesia telah menjadi teman regional China dengan penyediaan vaksin CoronaVac Sinovac melalui perusahaan farmasi Bio Farma. Uni Emirat Arab (UEA) memilih Sinopharm karena bersedia melakukan uji klinis fase tiga di UEA dan membangun kemampuan produksi vaksin asli. Sinopharm juga mengatur untuk memproduksi vaksinnya di UEA untuk distribusi regional.

Hanya dengan muncul dan membantu menutup kesenjangan dalam pasokan vaksin global, China telah memperoleh pijakan dalam diplomasi vaksin. Presiden Xi Jinping berjanji bahwa vaksin China akan diberikan sebagai barang publik global. Diplomasi vaksin telah membantu meningkatkan pengaruh China dan memungkinkannya memanfaatkan peluang baru. China telah mendistribusikan vaksin kepada negara-negara yang berpartisipasi dalam Belt and Road Initiative (BRI). Menurut laporan Think Global Health pada April 2021, dari 56 negara di mana China menjanjikan dosis, semua kecuali satu adalah peserta dalam BRI-nya. Dengan menyebutnya sebagai "Jalur Sutra Kesehatan", diplomasi vaksin telah memberikan pijakan bagi industri farmasi China. ${ }^{40}$

Tidak hanya China, India juga merupakan negara dengan pengaruh diplomasi vaksin yang kuat saat ini. Selama lebih dari dua dekade, India telah memperoleh reputasi sebagai "Apotek Dunia" karena industri farmasi generiknya yang telah memasok obatobatan terjangkau sesuai dengan standar kualitas ke pasar global. India menekankan kebijakan 'Neighbourhood First', mengadopsi pendekatan dua arah. Pertama, diaktifkan kembali SAARC (The South Asian Association of Regional Cooperation) sebagai forum untuk merumuskan rencana aksi regional untuk bersama-sama memerangi pandemi dan mengadopsi diplomasi bilateral untuk menjangkau negara tetangganya. Kedua,

$\overline{40}$ Khmarul Hidaya, "WHO: Sudah 184 Negara". secara bilateral memasok alat pengujian dan peralatan medis untuk membantu negara tetangganya mengatasi kekurangan pasokan. ${ }^{41}$

Di kawasan Asia Selatan Pemerintah India mendorong persaingan lebih kompetitif dan seimbang. Vaksin buatan India, di sisi lain, dilaporkan aman, hemat biaya. Vaksin India memerlukan penyimpanan dan memiliki biaya transportasi dengan harga yang sangat rendah. India telah mengekspor vaksin virus Covid-19 dosis baru ke negara tetangga. Pemerintah India telah mengirimkan vaksin tersebut ke Maladewa dan Bhutan sebagai hibah dan hadiah. Pengawas obat India menyetujui dua vaksin, yaitu Covishield oleh Serum Institute of India dan Covaxin oleh Bharat Biotech. India telah memasok 10 juta dosis vaksin ke Afrika dan satu juta untuk pekerja kesehatan PBB India di bawah fasilitas Akses Global Vaksin Covid-19 (COVAX) dari Aliansi Global untuk Vaksin dan Imunisasi (GAVI).

Rusia menggunakan vaksin Sputnik $\mathrm{V}$ untuk mendapatkan relasi diplomasi dengan negara lain. Moskow memberikan akses ke negara-negara yang belum dapat memulai program vaksinasi mereka sendiri. Tetapi dalam mengembangkan vaksin untuk penggunaannya sendiri, Global North mengabaikan biaya yang mahal dari Vaksin Pfizer-BioNTech, Moderna, dan Johnson Eु Johnson untuk negara-negara miskin.

Pada 16 Juli 2021, African Vaccine Acquisition Trust (AVAT), COVAX, dan Amerika Serikat mengumumkan sumbangan 25 juta vaksin Johnson \& Johnson Covid-19 ke 49 negaraAfrika.Afreximbankmemberlakukan Jaminan Komitmen Pengadaan di muka (Advance Procurement Commitment/APC) senilai 2 miliar dolar amerika untuk mendapatkan 400 juta dosis vaksin Johnson \& Johnson, dari total 620 juta dosis ke Afrika pada akhir

41 Biswajit Dhar, "India's Vaccine Diplomacy", Global Policy Journal, 8 April 2021, diakses pada 21 Juni 2021, https://www.globalpolicyjournal.com/ blog/08/04/2021/indias-vaccine-diplomacy. 
tahun 2021. Sebagian vaksin akan bersumber dari produksi berlisensi di Afrika Selatan. ${ }^{42}$ Sebagian vaksin tersebut didistribusikan oleh COVAX dengan tujuan untuk memvaksinasi 60 persen populasi. ${ }^{43}$

Tidak hanya Afrika, Amerika Serikat juga memberikan bantuan vaksin kepada Indonesia. Duta Besar Amerika Serikat untuk Indonesia Sung Y. Kim mengucapkan selamat kepada Indonesia atas kedatangan tiga juta dosis vaksin Moderna pemberian pemerintah Amerika Serikat pada 11 Juli lalu. Pemerintah Amerika Serikat akan memberikan satu juta dosis tambahan kepada Indonesia sebagai bagian dari tahap pengiriman vaksin ini. ${ }^{44}$

Diplomasi vaksin bagi negara produsen vaksin adalah memperkuat identitas dan hubungan teknologi yang akan datang antara negara-negara. Sebagai contoh, India mempromosikan kebijakan luar negeri dan hubungan diplomatik mereka dengan Selatan dan Utara. India sebelumnya telah memasok tablet hydroxychloroquine, remdesivir dan parasetamol, serta kit diagnostik, ventilator, masker, sarung tangan, dan pasokan medis lainnya ke sejumlah besar negara untuk membantu mereka menangani pandemi. ${ }^{45}$

\section{Diplomasi 'Hobbesian' Konfliktual}

Perseteruan Amerika Serikat (AS) dan China tidak berhenti meski dunia dilanda

42 Noah Higgins-Dunn, "Covid-19 Tracker: EMA Warns of A Possible Link Between Johnson \& Johnson Vax And Neurological Disorder; EU Lagging On Vaccine Donation Pledge", Fierce Pharma, diakses pada 10 September 2021, https://www.fiercepharma.com/ pharma/Covid-19-tracker-pfizer-vaccine-data-babiescould-come-by-september-spain-s-reig-jofre-to.

43 Global Vaccine Alliance, "Covid-19 Vaccines".

44 US Embassy Jakarta, "Amerika Serikat Berikan 4 Juta Dosis Vaksin Covid-19 Moderna untuk Indonesia Melalui COVAX”, US Embassy Jakarta, 11 Juli 2021, diakses pada 20 Juli 2021, https://id.usembassy.gov/ id/amerika-serikat-berikan-4-juta-dosis-vaksin-Covid19-moderna-untuk-indonesia-melalui-covax/.

45 Sumit Kumar, "Vaccine Diplomacy and Implication for Global Order", International Journal of Humanities and Sosial Science Invention (IJHSSI), Volume 10 Issue 4 Ser. II (April 2021) 2. pandemi Covid-19 sejak akhir tahun 2019. Ketika WHO menyerukan kerjasama multilateral dalam menghadapi pandemik Covid-19, Amerika Serikat bergeming tetap 'menyerang' China. Mulai dari Laut China Selatan, Perang Dagang (Trade War), Perang Siber (Cyber War), berlanjut hingga perang vaksin (Vaccine War).

Presiden Amerika Serikat Donald Trump (2017-2021) melakukan 'politik penamaan' (politics of naming) dengan menyebut Covid-19 sebagai Virus China (Chinese Virus). Menteri Luar Negeri Mike Pompeo juga menyebut Covid-19 sebagai virus Wuhan (Wuhan virus). Contoh tersebut adalah pola Hobbesian. Trump kemudian juga menyatakan AS keluar dari WHO pada 6 Juli $2020 .{ }^{46}$ Media dan para ilmuwan di Amerika Serikat secara umum tidak menyimpulkan Covid-19 sebagai kebocoran yang disengaja dari laboratorium di Wuhan. Namun pada April 2020 saat masih menjabat sebagai Presiden AS, Trump menuding pandemi Covid-19 sebagai konspirasi melalui kebocoran laboratorium karena virus tersebut menimbulkan malapetaka bagi perekonomian AS. ${ }^{47}$

Pemerintahan Trump juga menyatakan bahwa AS tidak akan bergabung dengan COVAX karena hubungannya dengan WHO. Namun setelah terpilih sebagai presiden dalam pemilihan Presiden 2020 lalu, Joe Biden mengumumkan bahwa AS akan tetap berada di WHO dan akan bergabung dengan COVAX pada 20 Januari 2021. Pembalikan kebijakan Amerika ini diumumkan oleh Kepala Penasihat Medis Presiden Anthony

46 Drew Hinshaw \& Stephanie Armour, "White House Says US Has Pulled Out of the World Health Organization", The Wall Street Journal, 7 Juli 2020, diakses pada 30 Juli 2021, https://www.wsj.com/ articles/white-house-says-u-s-has-pulled-out-of-theworld-health-organization-11594150928.

47 Tara McKelvey, "Teori Konspirasi Virus Corona Berasal Dari Laboratorium China Mengembalikan Donald Trump Ke Panggung Politik Di Amerika Serikat", BBC News, 29 Juni 2021, diakses pada 30 juli 2021, https:// www.bbc.com/indonesia/indonesia-57634681. 
Fauci. Pada 19 Februari, AS menjanjikan 4 miliar dolar Amerika kepada COVAX dan meenobatkannya sebagai kontributor tunggal terbesar untuk dana program tersebut.

Serangan AS dan sekutunya mendapat respons dari pemerintah China. Wakil Menteri Luar Negeri China Le Yucheng membantah tudingan Presiden Trump dan menyebutnya sebagai langkah AS mempolitisasi virus. Le bahkan menantang Presiden Trump untuk lebih serius mengendalikan penyebaran Covid-19 di negaranya sendiri. ${ }^{48}$ Pejabat Kementerian Luar Negeri China lainnya Zhao Lijian bahkan menuding balik dengan teori konspirasi yang menyebutkan bahwa intelijen militer AS yang membawa virus tersebut ke Wuhan. ${ }^{49}$ Perselisihan Trump dan Xi Jinping berlanjut ketika Sidang Umum PBB pada September 2020 lalu. Trump kembali konsisten dengan lebeling-nya terhadap Covid-19 sebagai 'Virus China' dan menuntut China untuk bertanggung jawab atas efek dari pandemi. Presiden Xi menolak tudingan politik virus yang dilontarkan Trump sembari menekankan bahwa China tidak bermaksud melakukan Perang Dingin dengan negara manapun. ${ }^{50}$

Beberapa negara yang memiliki kedekatan dengan AS mengeluarkan sikap tegas terhadap vaksin Sinovac yang diproduksi China. Misalnya, kebijakan Arab Saudi yang menyatakan keraguan terhadap vaksin

48 Janis Mackey Frayer and Adela Suliman, "Senior Chinese Official Challenges Trump Over Coronavirus Response, Says U.S. Wasted Weeks”, NBC News, 29 April 2020, diakses 30 Juli 2021, https://www.nbcnews. $\mathrm{com} /$ news/world/senior-chinese-official-challengestrump-over-coronavirus-response-says-u-n 1194371.

49 Ardi Priyatno Utomo, "Sebut Virus Corona "Chinese Virus”, Trump Buat China Marah”, KOMPAS, 17 Maret 2020, diakses pada 30 Juli 2021, https://www. kompas.com/global/read/2020/03/17/203430670/ sebut-virus-corona-chinese-virus-trump-buat-chinamarah? page $=$ all.

50 Aljazeera, "China: Trump 'Spreading Political Virus' At United Nations”, Aljazeera, 22 September 2020, diakses pada 30 Juli 2021, https://www.aljazeera.com/ news/2020/9/22/china-trump-spreading-politicalvirus-at-united-nations
Sinovac. Berdasarkan aturan Kerajaan Arab Saudi, jenis vaksin yang diperbolehkan diantaranya adalah vaksin Pfizer, Moderna, Astrazeneca dan Johnson \& Johnson. Arab Saudi menerapkan kebijakan suntikan tambahan kepada individu dengan merk-merk tersebut. ${ }^{51}$ Raja Salman bin Abdul Aziz bahkan menyatakan akan menghukum warganya yang melakukan bepergian ke beberapa negara seperti Afghanistan, Argentina, Brasil, Mesir, Ethiopia, India, Lebanon, Pakistan, Afrika Selatan, Turki, Vietnam, dan Uni Emirat Arab, termasuk Indonesia. ${ }^{52}$ Diketahui, negara-negara tersebut adalah negara yang menerima penggunaan vaksin Sinovac dalam mengendalikan.

Singapura salah satu negara maju di Asia Tenggara menolak penggunaan vaksin Sinovac. Singapura memperhatikan penggunaan vaksin yang diberikan kepada warganya. Hal ini terlihat dari bagaimana Singapura membedakan perlakuan bagi warganya yang disuntik vaksin Sinovac, Pfizer, dan Moderna. Vaksin Pfizer dan Moderna merupakan vaksin Covid-19 berbasis mRNA sebagaimana ditentukan dalam program nasional Singapura. ${ }^{53}$ Sedangkan Sinovac bukan termasuk vaksin program vaksinasi nasional. Meski begitu, kementerian telah mengizinkan penggunaan vaksin itu, di bawah lembaga kesehatan swasta di bawah

51 Aulia Nur Hakiki, "Umroh Kembali Diizinkan, Arab Saudi Tolak Jamaah yang Vaksin Menggunakan Sinovac", Pikiran Rakyat, 27 Juli 2021, diakses pada 29 Juli 2021, https://kabartegal.pikiran-rakyat. com/internasional/pr-932288565/umroh-kembalidiizinkan-arab-saudi-tolak-jamaah-yang-vaksinmenggunakan-sinovac.

52 Sylke Febrina Laureceno, "Raja Salman bakal Hukum Warganya yang Nekat Pergi ke Indonesia!", DETIKCOM, 30 Juli 2021, diakses pada 30 Juli 2021,https://finance.detik.com/berita-ekonomibisnis/d-5662365/raja-salman-bakal-hukum-warganyayang-nekat-pergi-ke-indonesia.

53 Aditya Jaya Iswara, "Singapura Bedakan Perlakuan untuk Penerima Vaksin Sinovac, Pfizer, dan Moderna”, KOMPAS, 1 Juli 2021, diakses pada 29 Juli 2021, https://www.kompas.com/global/ $\mathrm{read} / 2021 / 07 / 01 / 154939470 /$ singapura-bedakanperlakuan-untuk-penerima-vaksin-sinovac-pfizer-dan. 
program khusus. Program ini dilakukan pasca turunnya izin penggunaan darurat dari WHO. ${ }^{54}$ Perbedaan perlakuan penerima vaksin Sinovac dituntut melakukan tes Covid-19 jika akan menghadiri sebuah acara, sedangkan penerima vaksin Pfizer atau Moderna tidak perlu melakukannya. Dokter pun diwajibkan memberitahu penerima vaksin Sinovac di Singapura atas konsekuensi yang akan dihadapi. Perbedaan lain adalah kemungkinan penerima vaksin Sinovac juga tidak dapat menikmati pelonggaran lain dari Pemerintah Singapura.

Taiwan memesan tambahan 36 juta dosis vaksin Covid-19 Moderna dari AS. Sekitar 20 persen dari 23,5 juta penduduk di Taiwan telah menerima setidaknya satu dosis suntikan vaksin. ${ }^{55}$ Pemerintah China telah berulangkali hendak mengirim vaksin Sinovac ke Taiwan, namun justru Taiwan mengeluarkan keprihatinannya mengenai risiko keselamatan dari vaksin China. Oleh karena itu, persoalan bantuan vaksin dari dunia kepada Taiwan, khususnya dari AS, dianggap memperuncing konflik dengan China. ${ }^{56}$ China merespon dengan dingin keputusan AS mengirimkan vaksin ke Taiwan. Pola Hobbesian tidak hanya terlihat pada kasus China dengan AS dan sekutunya. Di Timur Tengah, Israel tidak memiliki itikad baik terhadap Palestina dalam konteks menghadapi pandemi Covid-19. Israel menyuplai vaksin yang telah kadaluarsa kepada

54 Tommy Patrio S, "Singapura Tak Pilih Sinovac di Program Vaksinasi Nasional”, CNBC Indonesia, 7 Juli 2021, diakses pada 28 Juli 2021, https://www. cnbcindonesia.com/news/20210707135638-4258991/singapura-tak-pilih-sinovac-di-programvaksinasi-nasional.

55 Natasha Khairunisa Amani, "Taiwan Tambah Pemesanan Vaksin Covid-19 Moderna menjadi 36 Juta Dosis", Liputan6, 22 Juli 2021, diakses pada 28 Juli 2021. https://www.liputan6.com/global/ $\mathrm{read} / 4613037 /$ taiwan-tambah-pemesanan-vaksinCovid-19-moderna-jadi-36-juta-dosis.

56 CNNIndonesia,"GeramChinaatasPaketBerjuta Vaksin dari AS untuk Taiwan”, CNN Indonesia, 21 juni 2021, diakses pada 28 Juli 2021, https://www.cnnindonesia. com/internasional/20210621125438-113-657198/ geram-china-atas-paket-berjuta-vaksin-dari-as-untuktaiwan.
Palestina. Sebelumnya Tel Aviv mengklaim vaksin Covid-19 yang dimilikinya kadaluarsa pada Juli 2021 dan Agustus 2021. Namun setelah dicek kembali vaksin itu ternyata telah kadaluarsa pada Juni 2021.

Selama berbulan-bulan, organisasi hak asasi manusia (HAM) telah meminta Israel, sebagai kekuatan pendudukan, untuk memberikan intervensi medis yang akan mendukung kampanye vaksinasi untuk yang tertinggal di wilayah Palestina. Tetapi Perdana Menteri Benjamin Netanyahu, menegaskan bahwa Otoritas Palestina bertanggung jawab atas kesehatan masyarakat di bawah ketentuan perjanjian Oslo. Israel sendiri merupakan salah satu negara dengan kampanye vaksinasi Covid-19 tercepat di dunia. Tel Aviv tercatat sudah memberikan dua dosis vaksin Covid-19 pada 57 persen penduduknya. Hal ini membuat otoritas negeri zionis itu mencabut beberapa protokol kesehatan seperti penggunaan masker.

\section{Tantangan Diplomasi}

Kasus Covid-19 di sejumlah negara kembali melonjak pada Februari hingga Juni 2021. Varian delta yang memiliki kemampuan penularan lebih cepat. Di Amerika Serikat aturan memakai masker di tempat umum kembali diterapkan setelah kasus harian meningkat tajam mencapai 57.126 kasus dalam sehari. Bahkan hingga akhir Agustus 2021, kasus harian di AS terus menembus angka 100 ribu jiwa. ${ }^{57}$ Peningkatan juga terjadi di Tokyo dan China. Di Tokyo beberapa hari setelah Olimpiade dimulai, kasus harian COVID-10 pecah rekor yakni sebanyak 2.848 kasus. Angka ini lebih banyak semenjak bulan Januari 2021 yakni 2.520 kasus. $^{58}$ Varian

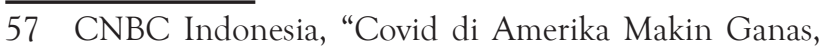
RS Kehabisan Oksigen” CNBC Indonesia, 30 Agustus 2021, diakses pada 10 September 2021, https:// www.cnbcindonesia.com/news/20210830093437-4272147/covid-di-amerika-makin-ganas-rs-kehabisanoksigen.

58 CNBC Indonesia, "Varian Delta Picu Melonjaknya 
Delta yang pertama kali dideteksi di India kini tercatat terdeteksi di 125 negara di dunia. Menurut WHO, lebih dari tiga perempat spesimen positif Covid-19 di sejumlah negara besar dunia tercatat adalah kasus varian delta. ${ }^{59}$

China melaporkan lonjakan infeksi Covid-19 karena penyebaran varian Delta di empat provinsi pada Kamis, 29 Juli 2021 - Lonjakan kasus bermula ketika sembilan pekerja bandara Nanjing dinyatakan positif Covid-19 pada 20 Juli lalu. Sejak itu, kasus meningkat mencapai 171 kasus di Provinsi Jiangsu hingga menyebar ke setidaknya empat provinsi lain. Ini merupakan penyebaran Covid-19 varian Delta terbesar secara geografis dalam beberapa bulan terakhir di China. Sejak klaster Covid-19 terdeteksi, bandara Nanjing telah melakukan pemeriksaan massal terhadap 9,2 juta warganya dua kali. ${ }^{60}$

Di tengah lonjakan kasus varian delta di berbagai negara, WHO menyampaikan data baru tentang penurunan efikasi vaksin-vaksin yang selama ini telah digunakan. Bukan hanya Sinovac asal China yang mengalami penurunan efikasi terhadap antibodi setelah enam bulan, vaksin Pfizer dari Jerman pun berdasarkan penelitian menunjukkan hal yang sama. ${ }^{61}$ Bahkan penemuan di Israel, efikasi vaksin Pfizer hanya 39 persen akibat varian

Kembali Kasus Covid-19 Dunia”, CNBC Indonesia, 28 Juli 2021, diakses pada 28 Juli 2021, https:// www.cnbcindonesia.com/news/20210728125712-8. 264285/varian-delta-picu-melonjaknya-kembali-kasusCovid-19-dunia.

59 CNN Indonesia, "WHO Prediksi Covid 19 Bakal Merajalela di Dunia", CNN Indonesia, 27 Juli 2021, diakses pada 28 Juli 2021https://www.cnnindonesia. com/internasional/20210722093630-134-670674/whoprediksi-Covid-19-varian-delta-bakal-merajalela-di-dunia.

60 CNN Indonesia, "China Lockdown Parsial Usai Varian Delta Menyebar Luas", CNN Indonesia, 29 Juli 2021, diakses pada 29 Juli 2021, https://www.cnnindonesia. com/internasional/20210729195315-113-674018/ china-lockdown-parsial-usai-varian-delta-menyebarmeluas,

61 CNN Indonesia, "Bos Pfizer Sebut Efikasi Vaksin Turun 84 Persen Usai 6 Bulan”, CNN Indonesia, 29 Juli 2021, diakses pada 29 juli 2021, https://www.cnnindonesia. com/teknologi/20210729141111-199-673811/bospfizer-sebut-efikasi-vaksin-turun-84-persen-usai-6-bulan. delta menjadi strain dominan. ${ }^{62}$

Efikasi adalah kemampuan vaksin untuk mencegah penyakit pada penerima vaksin. Berdasarkan data WHO, varian B1117 atau varian Alpha dari Inggris mempengaruhi efikasi vaksin AstraZeneca. Varian B1351 atau varian Beta dari Afrika Selatan mempengaruhi efikasi vaksin Moderna, Pfizer, AstraZeneca, dan Novavax. Sedangkan varian P1 atau gamma dari Brazil, dan varian B1617.2 atau delta dari India mempengaruhi efikasi vaksin Moderna dan Pfizer. ${ }^{63}$ Sebagaimana dikatakan Juru Bicara Satgas Penanganan Covid-19 Wiku Adisasmito, varian virus berpengaruh pada efikasi vaksin karena hampir seluruh vaksin yang digunakan saat ini menggunakan virus yang belum bermutasi atau original virus dari Wuhan China.

Kemampuan mutasi Covid-19 pada setiap fase penularannya secara tidak langsung berdampak pada kebijakan luar negeri dan diplomasi negara-negara dalam menghadapi pandemi. Kecepatan mutasi Covid-19 menjadi tantangan global, terutama pemimpin dunia dalam merancang kerjasama dan kolaborasi diplomatik dalam menghadapi pandemik. Pada satu sisi mobilitas horisontal manusia tidak dapat dihentikan hanya untuk memutus penularan, tapi di sisi lain sejauh ini belum ada negara yang benar-benar berhasil dengan kebijakan 'lockdown' yang diambil. Apalagi varian Delta dari India menunjukkan penularan yang cepat dan mampu menurunkan efikasi secara signifikan dari antibodi manusia. Umumnya tindakan yang diambil negara-negara dengan penduduk besar adalah

62 Rita Puspita Rachmawati, "Efikasi Vaksin Pfizer di Negara ini Turun jadi 39 Persen”, DETIKCOM, 25 Juli 2021, diakses pada 28 Juli 2021, https://health.detik. com/berita-detikhealth/d-5656052/efikasi-vaksinpfizer-di-negara-ini-turun-jadi-39-persen-ada-apa.

63 Anjar Saputra, "Efikasi Sejumlah Vaksin Covid 19 Dilaporkan Turun Karena Varian Baru Virus Corona”, GRID, 3 Juni 2021, diakses pada 28 juli 2021, https:// health.grid.id/read/352723796/efikasi-sejumlahvaksin-Covid-19-dilaporkan-turun-karena-varian-baruvirus-corona-ini-daftar-mereknya?page=all. 
kebijakan ketat-longgar. Pada saat terjadi lonjakan kasus, negara melakukan pengetatan mobilitas hingga ke tingkat 'lockdown'. Ketika kasus menurun, negara mengambil kebijakan pelonggaran.

Namun demikian, meski distribusi vaksin Covid-19 dilakukan melalui mekanisme COVAX, distribusi vaksin di berbagai negara tetap tidak merata. Terjadi ketimpangan antara negara kaya dan negara miskin. Diplomasi kompetitif di antara negara-negara kaya dalam memenuhi kebutuhan vaksinnya telah mengabaikan kebutuhan negara-negara miskin untuk memperoleh hak yang sama terkait vaksin. WHO meminta negara-negara kaya dengan pasokan vaksin melimpah untuk menahan pemberian booster Vaksin Covid-19 paling lambat hingga akhir tahun. Menurut Dirjen WHO, Tedros Adhanom Ghebreyesus 70 persen negara kaya sudah memvaksinasi 40 persen populasi mereka, sementara negara negara miskin masih jauh dari angka 40 persen populasi itu. ${ }^{64}$ Indonesia hingga 31 Agustus 2021 telah berhasil memberikan 100 juta lebih dosis vaksin dari target 416 juta vaksin untuk 208 juta populasi agar mencapai Herd Immunity. ${ }^{65}$

\section{Kesimpulan}

Pandemi Covid-19yang sudah berlangsung hampir dua tahun, telah menginterupsi globalisasi di segala bidang. Sebanyak 27,6 persen dari populasi dunia telah menerima sedikitnya satu dosis vaksin Covid-19, dan sekitar 14,1 persen telah mendapatkan penuh dua kali vaksin. ${ }^{66}$ Luasnya dampak yang

64 CNBC Indonesia, "WHO Minta Hentikan Booster Vaksin Covid-19", CNBC Indonesia, 9 September 2021, diakses pada 10 September 2021, https:// www.cnbcindonesia.com/news/20210909121200-8274913/who-minta-hentikan-booster-vaksin-Covid-19.

65 Kumparan, "Target 100 juta Suntikan Vaksin di Indonesia Tercapai”, Kumparan, 31 Agustus 2021, diakses pada 9 September 2021, https://kumparan. $\mathrm{com} /$ kumparannews/target-100-juta-suntikan-dosisvaksin-di-indonesia-tercapai-1wRKIrQ8FMU/2.

66 Our World In Data, "Coronavirus Vaccinations", Our World in Data, diakses pada 28 Juli 2021, https:// ditimbulkan dari pandemi seharusnya disikapi dengan kerjasama dan kolaborasi di antara aktor-aktor politik internasional.

Pada era keterbukaan globalisasi dan teknologi saat ini, seharusnya penanganan terhadap pandemik virus lebih baik dibandingkan dengan situasi sistem internasional sebelum Perang Dunia I (seperti pada kasus Flu Spanyol), dimana system internasional saat itu masih bersifat tertutup, rahasia dan tidak memprioritaskan kerjasama internasional. Pandemik Covid-19 yang sedang berlangsung sekarang pada kenyataannya telah menunjukkan sifat anarki sistem internasional yang berlaku di era keterbukaan saat ini, masih menyisakan pola-pola diplomasi yang beragam.

Ilmuwan politik internasional Alexander Wendt menyebutkan, sifat anarki dari sistem internasional memunculkan tiga pola budaya anarki, yaitu pola Hobbesian (Thomas Hobbes), Lockean (John Locke) dan Kantian (Immanuel Kant). Ketiga pola ini selalu tercipta dalam dinamika politik internasional yang berlangsung, termasuk dalam situasi saat ini dimana dunia dilanda pandemik Covid-19. WHO melalui COVAX melakukan manajerial ditribusi vaksin dengan tujuan pemerataan distributif. Multilateralisme COVAX menunjukkan pola Kantian dalam diplomasi vaksin. Tapi ketidakmerataan bahkan ketimpangan penggunaan vaksin antara negara kaya dan negara miskin menunjukkan bagaimanapun perebutan kompetitif vaksin tidak dapat dihindarkan. Di luar itu, konflik AS dan China yang sudah terjadi sebelum pandemi, turut menghangatkan konstelasi diplomasi vaksin yang berlangsung, di mana tidak hanya AS, tapi sejumlah negara sekutunya ikut memboikot penggunaan vaksin asal China.

ourworldindata.org/covid-vaccinations. 


\section{DAFTAR PUSTAKA}

Barston, RP. Modern Diplomacy,(New York: Longman, 1997).

Djelantik, Sukawarsini, Diplomasi antara Teori dan Praktik, (Yogyakarta: Graha Ilmu, 2008).

Hotez, Peter J, "Vaccine Diplomacy: Historical Perspectives and Future Directions", PLoS Negl Trop, Dis 8(6), (Juni 2014).

Jackson, Robert, et. al. Pengantar Studi Hubungan Internasional: Teori dan Pendekatan, (Yogyakarta: Pustaka Pelajar, 2016).

Katz R. et. al. "Defining Health Diplomacy: Changing Demands in the Era of Globalization”, Milbank Quarterly 89, (September 2011).

Kickbusch, et al. "Global Health Diplomacy: The Need for New Perspectives, Strategic Approaches and Skills in Global Health”, Bull World Health Organ 85 (Maret 2007).

Kickbusch, et al. "Global health diplomacy: five years on", Bull World Health Organ 91 (Maret 2013).

Kumar, Sumit. "Vaccine Diplomacy and Implication for Global Order", International Journal of Humanities and Sosial Science Invention (IJHSSI), Volume 10 Issue 4 Ser. II (April 2021).

McDonald, John W. "The Institute for MultiTrack Diplomacy", Journal of Conflictology, Vol. 3, Iss. 2 (2012).

Pattanaik, Smruti S. "Covid-19 Pandemik and India's Regional Diplomacy”. Sage Journals. 28-1,(Maret 2021).

Pearson, J Diane, "Medical diplomacy and the American Indian: Thomas Jefferson, the Lewis and Clark Expedition, and the subsequent effects on American Indian health and public policy". Wicazo S Review 19 (2004).
Satow, Sir Ernest, A Guide to Diplomatic Practice, (New York: Longman Green \& Co, 1922).

Wangke, Humphrey, "Diplomasi Vaksin Indonesia untuk Kesehatan Dunia”. Info Singkat DPR. Vol.XIII, No 1, (Januari 2021).

Watson, Adam, The Dialogue Between States, (London: Methuem, 1984).

Wendt, Alexander, Social Theory of International Politics,(Cambridge: Cambridge University Press, 1999).

Yusuf, A. Muri, Metode Penelitian Kuantitatif, Kualitatif, dan Penelitian Gabungan. (Jakarta: Kencana, 2019).

\section{Internet}

Amani, Natasha Khairunisa. "Taiwan Tambah Pemesanan Vaksin Covid-19 Moderna menjadi 36 Juta Dosis", Liputan6, 22 Juli 2021, diakses pada 28 Juli 2021, https://www.liputan6.com/ global/read/4613037/taiwan-tambahpemesanan-vaksin-Covid-19-moderna-jadi36-juta-dosis.

Aivanni, Nur. "Indonesia Bergabung dalam COVAX”, Media Indonesia, 16 Oktober 2021, diakses pada 28 Juli 2021, https://mediaindonesia.com/ internasional/353486/menlu-indonesiabergabung-dalam-covax-amc.

Beer, Tommy. "U.S. Won't Join Global Coronavirus Vaccine Effort Because It's Led By The WHO”, FORBES, 1 September 2020, diakses pada 28 Juli 2021. https://www.forbes.com/sites/ tommybeer/2020/09/01/us-wont-joinglobal-coronavirus-vaccine-effort-becauseits-led-by-the-who/?sh=14cb9e575876

Biswajit Dhar, "India's Vaccine Diplomacy", Global Policy Journal, 8 April 2021, diakses pada 21 Juni 2021, https:// www.globalpolicyjournal.com/ blog/08/04/2021/indias-vaccinediplomacy, 
CNBC Indonesia, "Covid di Amerika Makin Ganas, RS Kehabisan Oksigen" CNBC Indonesia, 30 Agustus 2021, diakses pada 10 September 2021, https://www.cnbcindonesia.com/ news/20210830093437-4-272147/coviddi-amerika-makin-ganas-rs-kehabisanoksigen,

CNBC Indonesia, "Varian Delta Picu Melonjaknya Kembali Kasus Covid-19 Dunia”, CNBC Indonesia, 28 Juli 2021, diakses pada 28 Juli 2021, https://www.cnbcindonesia.com/ news/20210728125712-8-264285/variandelta-picu-melonjaknya-kembali-kasusCovid-19-dunia,

CNBC Indonesia, "WHO Minta Hentikan Booster Vaksin Covid-19”, CNBC Indonesia, 9 September 2021, diakses pada 10 September 2021, https://www.cnbcindonesia.com/ news/20210909121200-8-274913/whominta-hentikan-booster-vaksin-Covid-19

CNN Indonesia, "WHO Prediksi Covid 19 Bakal Merajalela di Dunia”, CNN Indonesia, 27 Juli 2021, diakses pada 28 Juli 2021https://www. cnnindonesia.com/internasion $\mathrm{al} / 20210722093630-134-670674 /$ whoprediksi-Covid-19-varian-delta-bakalmerajalela-di-dunia,

CNN Indonesia, "China Lockdown Parsial Usai Varian Delta Menyebar Luas”, CNN Indonesia, 29 Juli 2021, diakses pada 29 Juli 2021, https:// www.cnnindonesia.com/internasio nal/20210729195315-113-674018/ china-lockdown-parsial-usai-varian-deltamenyebar-meluas,

CNN Indonesia, "Bos Pfizer Sebut Efikasi Vaksin Turun 84 Persen Usai 6 Bulan”, CNN Indonesia, 29 Juli 2021, diakses pada 29 juli 2021, https:// www.cnnindonesia.com/teknolo gi/20210729141111-199-673811/bospfizer-sebut-efikasi-vaksin-turun-84-persenusai-6-bulanSatuan Tugas Penanganan Covid-19, "Data Sebaran Covid-19 di Indonesia”, Satgas Covid19, Diakses pada 11 September 2021, https://covid19. go.id/

CNN Indonesia, "Geram China atas Paket Berjuta Vaksin dari AS untuk Taiwan”, CNN Indonesia, 21 juni 2021, diakses pada 28 Juli 2021, https:// www.cnnindonesia.com/internasion al/20210621125438-113-657198/geramchina-atas-paket-berjuta-vaksin-dari-asuntuk-taiwan

Covid-19 Corona Virus Pandemic, Worldometer, diakses pada 11 September 2021, https://www.worldometers.info/ coronavirus.

Fakultas Kehutanan IPB, "10 Wabah Global Terburuk di Era Modern”, Forest Digest, 23 Mei 2020, diakses pada 27 Juli 2021, https://www.forestdigest.com/ detail/525/10-wabah-global-terburuk-diera-modern,

Frayer , Janis Mackey., and Adela Suliman, "Senior Chinese Official Challenges Trump Over Coronavirus Response, Says U.S. Wasted Weeks”, NBC News, 29 April 2020, diakses 30 Juli 2021, dalam https:// www.nbcnews.com/news/world/seniorchinese-official-challenges-trump-overcoronavirus-response-says-u-n 1194371

Global Vaccine Alliance, "The Power of Partnership", GAVI, diakses 27 Juli 2021, https://www.gavi.org/our-alliance/about

Global Vaccine Alliance, "Covid-19 Vaccines are Now Approved Some Countries: What will it take Approve them?", GAVI, diakses 28 Juli 2021, dalam https://www. gavi.org/vaccineswork/Covid-19-vaccinesare-now-approved-some-countries-what- 
will-it-take-approve-them?gclid=CjwKCA jwgISIBhBfEiwALE19SbuVyJJi5StzX6Y ZU7sdYrvw3S1RfKagRwQeO4EviGn Wx7_-ggiVhoCljQQAvD_BwE

Hakiki, Aulia Nur. "Umroh Kembali Diizinkan, Arab Saudi Tolak Jamaah yang Vaksin Menggunakan Sinovac", Pikiran Rakyat, 27 Juli 2021, diakses pada 29 Juli 2021, https://kabartegal.pikiranrakyat.com/internasional/pr-932288565/ umroh-kembali-diizinkan-arab-saudi-tolakjamaah-yang-vaksin-menggunakan-sinovac

Higgins-Dunn, Noah. "Covid-19 Tracker: EMA Warns of A Possible Link Between Johnson \& Johnson Vax And Neurological Disorder; EU Lagging On Vaccine Donation Pledge", Fierce Pharma, diakses pada 10 September 2021, https://www. fiercepharma.com/pharma/Covid-19. tracker-pfizer-vaccine-data-babies-couldcome-by-september-spain-s-reig-jofre-to

Hinshaw, Drew. \& Stephanie Armour, "White House Says US Has Pulled Out of the World Health Organization", The Wall Street Journal, 7 Juli 2020, diakses pada 30 Juli 2021, https://www.wsj.com/ articles/white-house-says-u-s-has-pulledout-of-the-world-health-organization11594150928Suisheng Zhao, "Why China's vaccine diplomacy is winning". East Asian Forum, 29 April 2021, diakses pada 20 Juni 2021, https://www. eastasiaforum.org/2021/04/29/whychinas-vaccine-diplomacy-is-winning/

Iswara, Aditya Jaya. "Singapura Bedakan Perlakuan untuk Penerima Vaksin Sinovac, Pfizer, dan Moderna", KOMPAS, 1 Juli 2021, diakses pada 29 Juli 2021, https://www.kompas.com/ global/read/2021/07/01/154939470/ singapura-bedakan-perlakuan-untukpenerima-vaksin-sinovac-pfizer-dan,
Khomarul Hidayat, "WHO: Sudah 184 Negara Bergabung dengan COVAX untuk Dapat Akses Setara Vaksin Corona”, KONTAN, 20 Oktober 2020, diakses pada 27 Juli 2021, https://internasional.kontan.co.id/ news/who-184-negara-sudah-bergabungdengan-covax-untuk-dapat-akses-setaravaksin-corona

Kumparan, "Target 100 juta Suntikan Vaksin di Indonesia Tercapai”, Kumparan, 31 Agustus 2021, diakses pada 9 September 2021, https://kumparan.com/kumparannews/ target-100-juta-suntikan-dosis-vaksin-diindonesia-tercapai-1wRKIrQ8FMU/2,

Laureceno, Sylke Febrina. "Raja Salman bakal Hukum Warganya yang Nekat Pergi ke Indonesia!”, DETIKCOM, 30 Juli 2021, diakses pada 30 Juli 2021, https:// finance.detik.com/berita-ekonomibisnis/d-5662365/raja-salman-bakal-hukumwarganya-yang-nekat-pergi-ke-indonesia,

McKelvey, Tara. "Teori Konspirasi Virus Corona Berasal Dari Laboratorium China Mengembalikan Donald Trump Ke Panggung Politik Di Amerika Serikat", BBC News, 29 Juni 2021, diakses pada 30 juli 2021, https://www.bbc.com/ indonesia/indonesia-57634681,

Nebehay, Stephanie. "U.S Staying In WHO, To Join COVID Vaccine Push For Poor Nations: Fauci”. REUTERS, 21 Januari 2021, diakses pada 20 Juli 2021, https:// www.reuters.com/article/us-healthcoronavirus-who-usa-idUSKBN29Q12B

Our World In Data, "Coronavirus Vaccinations", Our World in Data, diakses pada 28 Juli 2021, https:// ourworldindata.org/covid-vaccinations,

Rachmawati, Rita Puspita. "Efikasi Vaksin Pfizer di Negara ini Turun jadi 39 Persen", DETIKCOM, 25 Juli 2021, diakses pada 28 Juli 2021, https://health.detik.com/ berita-detikhealth/d-5656052/efikasivaksin-pfizer-di-negara-ini-turun-jadi-39persen-ada-apa, 
RatihWaseso,"Indonesia TelahMengamankan 440 Juta Dosis Vaksin Covid-19", KONTAN, 29 Juli 2021, diakses pada 29 Juli 2021, https://nasional.kontan.co.id/ news/pemerintah-telah-mengamankan440-juta-dosis-vaksin-Covid-19

Saputra, Anjar. "Efikasi Sejumlah Vaksin Covid 19 Dilaporkan Turun Karena Varian Baru Virus Corona”, GRID, 3 Juni 2021, diakses pada 28 juli 2021, https:// health.grid.id/read/352723796/efikasisejumlah-vaksin-Covid-19-dilaporkanturun-karena-varian-baru-virus-corona-inidaftar-mereknya?page $=$ all.

Sorongan, Tommy Patrio. "Parah! Israel Beri Palestina Vaksin Covid-19 Kadaluarsa”, CNBCIndonesia,21Juni2021, diaksespada 28 Juli 2021, https://www.cnbcindonesia. com/news/20210621121708-4-254670/ parah-israel-beri-palestina-vaksin-Covid19-kadaluarsa,

Sorongan, Tommy Patrio, "Singapura Tak Pilih Sinovac di Program Vaksinasi Nasional", CNBC Indonesia, 7 Juli 2021, diakses pada 28 Juli 2021, https://www.cnbcindonesia. com/news/20210707135638-4-258991/ singapura-tak-pilih-sinovac-di-programvaksinasi-nasional.

Utomo, Ardi Priyatno. "Sebut Virus Corona "Chinese Virus", Trump Buat China Marah", KOMPAS, 17 Maret 2020, diakses pada 30 Juli 2021, https://www.kompas.com/global/ $\mathrm{read} / 2020 / 03 / 17 / 203430670 / \mathrm{sebut}$ virus-corona-chinese-virus-trump-buatchina-marah?page $=$ all

Victor Maulana, "China Desak AS Tidak lakukan Manipulasi Politik Setelah Kirim Vaksin ke Taiwan”, Sindo News, 22 Juni 2021, diakses pada 28 Juli 2021, https://international.sindonews.com/ $\mathrm{read} / 462474 / 40 /$ china-desak-as-tidaklakukan-manipulasi-politik-setelah-kirimvaksin-ke-taiwan-1624284364,. 